\title{
Permodelan Spasial pada Analisis Faktor yang Mempengaruhi Tingkat Pengangguran Terbuka Provinsi Bangka Belitung Tahun 2018
}

\author{
Apriliansyah Mahmud ${ }^{1}$, Ernawati Pasaribu ${ }^{2 *}$ \\ 1,2 Program Studi Diploma IV Statistika, Jurusan Statistika dan Kependudukan, \\ Politeknik Statistika STIS, \\ Jakarta, Indonesia 11480 \\ 211709567@stis.ac.id; ernawatipasaribu@stis.ac.id \\ *Correspondence: ernawatipasaribu@stis.ac.id
}

\begin{abstract}
Unemployement is a multidimensional problem that have wide impact into progress and quality of one area. Based on that problem, it is necessary to have an analysis of factor that affected this phenomena. One economy phenomenon of one area can be influenced by neighborhood economy activity. The purpose of this study is to know factors that affected open unemployemnet rate also answer the problem of neighborhood effect by spatial model. Based on result, variables that having spatial effect are open unemployement rate, count of poor citizen, and also gross domestic product. Beside of that, it is also known that error spatial model is feasible to be a model because having smallest Akaike Information Criteria score.
\end{abstract}

Keywords: Spatial lag; Spatial effect; Open Unemployement Rate.

\begin{abstract}
Abstrak-Pengangguran merupakan sebuah permasalahan multidimensional yang dapat berdampak luas terhadap kemajuan dan kualitas suatu daerah. Atas dasar tersebut perlu dilakukan kajian terhadap faktor-faktor yang mempengaruhi fenomena ini. Suatu fenomena perekonomian suatu wilayah dapat dipengaruhi oleh aktivitas perekonomian wilayah lain yang berdekatan. Penelitian ini bertujuan selain untuk mengetahui faktorfaktor yang mempengaruhi tingkat pengangguran terbuka juga untuk menjawab atas permasalahan keterkaitan antar wilayah tersebut melalui model spasial. Dari hasil analisis, variabel yang diduga memiliki keterkaitan wilayah adalah variabel tingkat pengangguran terbuka, jumlah penduduk miskin serta pendapatan regional daerah bruto. Selain itu, diketahui juga bahwa model spasial error layak digunakan dalam permodelan sebab memiliki nilai Akaike Information Criteria paling kecil.
\end{abstract}

Kata Kunci: Spatial lag; Efek spasial; TPT.

\section{PENDAHULUAN}

Pengangguran masih menjadi salah satu permasalahandiberbagainegara. Masalahiniperluditanganai secara serius oleh pemerintah dalam rangka pemanfaatan sumberdaya manusia yang optimal untuk pembangunan suatu negara Fenomna pengangguran merupakan akar dari masalah sosial lain seperti kemiskinan, kriminalitas hingga sosial dan budaya. Pengangguran merupakan masalah kompleks yang mempengaruhi sekaligus dipengaruhi oleh banyak faktor yang berinteraksi mengikuti pola yang tidak selalu mudah untuk dipahami (Muslim, 2014). Sulitnya mencari pekerjaan dikarenakan banyakanya penduduk tidak sebanding dengan jumlah lapangan pekerjaan menjadi salah satu faktor dari fenomena pengangguran. Badan Pusat Statistik, pada proyeksi penduduk tahun 2018 mencatat penduduk Indonesia mencapai 265 juta jiwa dengan konsentrasi penduduk berada pada kelompok golongan produktif yaitu 15 - 46 tahun. Sedangkan, laju pertumbuhan penduduk hingga tahun 2015 mencapai 1.38 persen per tahun. Pada tahun 2035, diperkirakan Indonesia akan mencapai jumlah penduduk mencapai lebih dari tiga ratus juta penduduk dengan dominasi kelompok umur berada pada kelompok umur produktif yaitu $15-46$ tahun. Atas dari fenomena ini, Indonesia diperkirakan akan mencapai suatu fenomena bonus demografi dimana kelompok usia produktif yang melimpah dapat dimanfaatkan dalam peningkatan kualitas suatu negara. Namun, hal ini justru menjadi kontras jika pengangguran masih menjadi salah satu masalah atas lonjakan penduduk yang terjadi.

Dalam konsep ketenagakerjaan, Badan Pusat Statistik mendefinisikan beberapa hal. Seseorang dinyatakan dalam kelompok angkatan kerja jika berumur lima belas tahun atau lebih yang bekerja, atau punya pekerjaan namun sementara tidak bekerja dan pengangguran. Pengangguran 
berdasarkan ciri-ciri menurut Sukirno (2010), dikategorikan sebagai pengangguran terbuka, pengangguran tersembunyi, pengangguran musiman, dan setengah menganggur. Pengangguran terbuka adalah kondisi dimana benarbenar tidak mempunyai pekerjaan. Pengangguran ini bisa diakibatkan oleh kegiatan ekonomi yang menurun, kemajuan teknologi industri, atau kemunduran perkemabngan suatu industri. Pengangguran tersembunyi adalah kondisi dimana tenaga kerja yang dipekerjakan melebihi yang dibutuhkan. Pengangguran ini terjadi pada sektor pertanian dan jasa. Pengangguran musiman adalah kondisi dimana seseorang tidak bekerja disebabkan faktor musim. Sebagai contoh, ketika musim yang tidak sesuai dengan jenis tumbuhannya, petani kebun cenderung tidak aktif. Jenis terakhir adalah penganguran setengah menganggur dimana seseorang mengalami penurunan produktivitas kerja. Philip (1997) menjelaskan bahwa ada tiga hal yang perlu dilihat sebagai dasar pengangguran terbuka yaitu kurangnya jam kerja, rendahnya pendapatan, dan ketidaksesuaian antara pekerjaan dengan pendidikan. Indikator yang digunakan dalam menilai pengangguran sebagai kualitas ketenagakerjaan adalah menggunakan pengangguran terbuka.

Pengangguran terbuka memberikan banyak dampak terhadap masalah multidimensional. Tingginya pengangguran akan menurunkan kesejahteraan masyarakat karena pendapatan yang diperoleh menurun. Kesejahteraan masyarakat yang semakin menurun akan menimbulkan masalah baru yaitu kemiskinan (Sukirno, 2006). Pengangguran juga dapat disebabkan karena rendahnya kualitas sumber daya manusia yang tercermin dari nilai Indeks Pembangunan Manusia (IPM). IPM merupakan suatu angka yang mengukur capaian pembangunan manusia berbasis sejumlah komponen dasar kualitas hidup yang dapat mempengaruhi tingkat produktivitas yang dihasilkan seseorang (Saputra,2011). Kesejahteraan masyarakat dan IPM antar daerah cenderung beragam. Keragaman ini dapat disebabkan oleh struktur ekonomi maupun struktur geografisnya. Struktur ekonomi dan penunjang kehidupan yang berbeda-beda menyebabkan angka pengangguran di setiap kabupaten kota tidaklah sama. Namun, tidak menutup kemungkinan bahwa suatu fenomena terkait antar wilayah. Elhorst (2014) suatu indikator atau variabel bebas dapat memiliki dua efek, yang pertama memiliki efek langsung (direct effect) terhadap wilayah yang diamati dan memiliki efek tidak langsung (spillover/indirect effect) terhadap wilayah lain.

Provinsi Bangka Belitung merupakan salah satu daerah di Indonesia yang selalu mengalami permasalahan pengangguran terbuka. Berdasarkan data Badan Pusat Statistik (BPS) tren pengangguran terbuka mulai tahun 2013 hingga 2018 adalah fluktuatif. Selanjutnya, jumlah penduuk yang selalu meningkat setiap tahun sebab provinsi Bangka Belitung memiliki laju pertumbuhan sebesar 2.02. Petumbuhan penduduk ini menyebabkan semakin banyak penduduk yang tidak memiliki pekerjaan. Lebih lanjut jumlah penduduk miskin di provinsi bangka Belitung juga meningkat sejalan dengan naik turunnya angka pengangguran. Indeks Pembangunan Manusia provinsi Bangka Belitung pada tahun 2018 adalah sebesar 71.30. Angka ini termasuk cukup baik dibandingkan tahun- tahun sebelumnya dan tidak jauh berbeda angka Indeks Pembangunan Manusia Indonesia yaitu sebesar 71.39.

Banyak penelitian yang telah membahas tentang pengangguran terbuka dan dikatikan dengan atau tanpa aspek kewilayahan Penelitian yang dilakukan oleh Rita Rahmawati dari Universitas Diponegoro pada tahun 2015 meneliti pengaruh tingkat pengangguran terhadap kemiskinan di Indonesia di provinsi Jawa Tengah dengan menggunakan spatial error model memberikan hasil bahwa tingkat pengangguran terbuka berpengaruh signifikan terhadap jumlah penduduk miskin. Penelitian yang dilakukan oleh Dwi Mahroji dari STIE Pandu Madania pada tahun 2019 meneliti pengaruh indeks pembangunan manusia terhadap tingkat pengangguran di provinsi Banten dengan menggunakan metode regresi data panel memberikan hasil bahwa variabel IPM berpengaruh signifikan terhadap jumlah pengangguran. Penelitian yang dilakukan oleh Putri Rohmadhoni dari Universitas Padjajaran pada tahun 2018 meneliti pengaruh produk domestic regional bruto (PDRB) daerah terhadap pertumbuhan ekonomi dan tingkat pengangguran terbuka di provinsi DKI Jakarta memberikan hasil bahwa variabel PDRB berpengaruh positif dan signifikan terhadap angka pengangguran.

Tujuan dari penelitian ini adalah untuk mengetahui model yang tepat dalam permodelan tingkat pengangguran terbuka terhadap jumlah penduduk miskin ,indeks pembangunan manusia serta produk domestic bruto dengan melibatkan efek kewilayahan (spasial).

\subsection{Model Regresi Linear Berganda}

Sebuah fenomena disusun atas beberapa faktor penyusun fenomena tersebut dan memiliki hubungan tersendiri antar fenomena. Hubungan ini kemudian dibahas dalam suatu kajian bernama regresi. Analisis regresi merupakan gambaran hubungan matematis antara fenomena dengan penyusunnya. Model dari regresi berganda secara matematis adalah sebagai berikut

$$
Y=\beta_{0}+\sum_{i=1}^{p} \beta_{i} X_{i}+\varepsilon_{i}
$$

dimana :

$Y=$ Variabel respons (terikat)

$X_{i}=$ Variabel bebas $, i=1,2,3, \ldots, p$

$\beta_{0}=$ Konstanta

$\beta_{\mathrm{i}}=$ Koefisien variabel bebas $-i, i=1,2,3, \ldots, p$

$\varepsilon_{i}=$ Nilai error regresi

(Neter, 2004)

Nilai koefisien merupakan estimasi suatu parameter. Nilai $\beta_{i}$ mengindikasikan perubahan dari nilai $\mathrm{Y}$ setiap kenaikan satu unit $\mathrm{X}$.

\subsection{Asumsi $O L S$}

Estimasi suatu parameter dapat dilakukan dengan estimasi kuadrat terkecil atau Ordinary Least Square (OLS). Metode OLS adalah metode untuk mengestimasi suatu garis regresi dengan jalan meminimalkan jumlah kuadrat kesalahan dari setiap observasi terhadap garis tersebut (Kuncoro, 2003). Suatu model yang baik memenuhi asumsi regresi linear agar memperoleh estimator yang memiliki varians minimum (Rawlings, 1932). Menurut Gujarati 
(1995). estimator OLS yang baik harus memenuhi kriteria BLUE (Best Liner Unbiased Estimate) dimana estimator tersebut adalah terbaik (Best), kombinasi linear dari sampel, nilai estimasi sesuai dengan harapan, dan efisien sebab memiliki nilai varians minimum. Rawlings (1932) menyebutkan beberapa asumsi yang harus dipenuhi:

1. Normalitas, dimana error regresi (residual) berdistribus normal dengan rataan nol dan memiliki ragam konstan. Ketika hanya asumsi terlanggar maka selang kepercayan menjadi tidak tepat.

2. Non-Autokorelasi, asumsi ini terlanggar jika error pengamatan saat ini berkorelasi dengan error pengamatan sebelumnya. Jika hal ini terlanggar maka nilai ragam dari estimator menjadi bias.

3. Homoskedastisitas, asumsi ini menjamin bahwa nilai varians yang ada adalah konstan. Imbas dari tidak terpenuhinya asumsi ini adalah presisi estimasi yang dihasilkan menjadi kecil.

4. Non-Multikolinearitas, asumsi ini tidak terpenuhi jika variabel bebas yang ada saling berhubungan atau merupakan fungsi variabel bebas lain yang secara bersamaan terdapat pada model. Dampak yang terjadi adalah tanda yang ada pada setiap estimator akan berbeda pada tanda yang terdapat di matriks korelasi antar variabel serta nilai standar eror yang besar sehingga pengaruh variabel bebas terhadap variabel terikat tidak dapat terdeteksi.

\subsection{Analisis Data Spasial}

Suatu letak geografis tersusun atas suatu informasi tidak hanya mengenai identitas wilayah tersebut namun pengetahuan lain. Kombinasi ini menggambarkan atributatribut pada bermacam fenomena seperti umur seseorang, tipe jalan, dan lainnya yang secara bersama dengan informasi seperti dimana seseorang tinggal atau lokasi suatu jalan (Keele,1997). Analisis data spasial secara umum menganlisis informasi tadi menggunakan sistem informasi geografis baik pemetaan maupun permodelan.

\subsection{Regresi Spasial}

Tobbler (1970) mengungkapkan hukum pertama geografi yang berbunyi :

"everything is related to everything else, but near things are more related than distant things".

Teori ini selanjutnya menjadi permulaan dari penemuan ketergantungan spasial dan keterkaitan spasial. Seperti yang telah dijelaskan sebelumnya bahwa estimator yang baik adalah estimator yang BLUE serta memenuhi asumsi OLS. Jika variabel terikat,variabel bebas serta nilai residual memiliki ketergantungan spasial maka model OLS yang dihasilkan bias dan tidak konsisten (Fischer,2011). Maka, solusi atas permasalahan tersebut dimana ketergantungan serta korelasi antar wilayah akan di ikut sertakan ke dalam model membutuhkan regresi spasial Manski (1993) menyebutkan tiga tipe interaksi spasial dimana:

1. Interaksi endogen, wilayah geografis akan mempengaruhi keputusan tetangga sekitar

2. Ineteaksi eksogen, karakteristik yang diobservasi mempengaruhi karakteristik tetangga sekitar
3. Korelasi spasial, efek dari karakteristik yang sama dan tidak di observasi.

Kemudian, elhorst (2010) menterjemahkan model umum Manski (1993) sebagai:

$$
Y=\alpha+X \beta+\rho W Y+\theta W X+u
$$

$$
u=\lambda W u+\varepsilon
$$

dimana :

$\alpha=$ Konstatnta

$\rho=$ Parameter interaksi variabel endogen

$\beta=$ Parameter variabel eksogen

$\theta=$ Parameter interajsi variabel eksogen

$\lambda=$ Efek korelasi error spasial

$W=$ Matriks penimbang spasial

Model spasial diatas merupakan interaksi dari seluruh parameter spasial yang ada. Namun, tidak semua kejadian spasial akan mengikuti pola model diatas.

\subsection{Dependensi dan Heterogenitas Spasial}

Efek spasial yang terdapat dalam ekonometrika , menurut Anselin (1988), ada dua jenis yaitu efek dependensi spasial dan efek heterogenitas spasial. Dependensi spasial menunjukkan adanya keterkaitan antar lokasi objek penelitian sedangkan heterogenitas spasial menunjukkan keragaman bentuk fungsional dan parameter sesuai lokasi.

\subsection{Spatial Error Model}

Model spatial error merupakan permodelan variabel terikat dengan variabel bebas namun dalam kondisi error terdapat korelasi spasial (Anselin, 1988), Pada persamaan (1.2), spatial error model (SEM) akan didapat jika tidak terdapat interaksi variabel endogen $(\rho=0)$ dan tidak terdapat inetraksi variabel eksoge $(\theta=0)$ (Elhorst,2013). Mska persamaan (1.2) menjadi:

$$
Y=\alpha+X \beta+u ; u=\lambda W u+\varepsilon
$$

Selanjutnya, persamaan ini merupakan prsamaan dari model spasial error (SEM).

\subsection{Spatial Lag Model}

Pada persamaan (1.2), variabel terikat antar wilayah dapat saling berinteraksi namun tidak terjadi interaksi variabel endogen serta tidak terjadi korelasi error antar wilayah $(\theta=0 ; \lambda=0)$. Model ini kemudian disebut sebagai spatial lag model. Maka persamaan (1.2) menjadi:

$$
Y=\alpha+X \beta+\rho W Y+\varepsilon
$$

Jika diturunkan, maka persamaan (1.5) akan memenuhi orde pertama model autoregressive dimana model meregresikan variabel bebas dan variabel terikat pengamatan lain secara bersamaan kedalam model.

\subsection{Estimasi Parameter}

Estimasi parameter model dilakukan dengan metode Maximum Likelihood Estimation. Berasal dari bentuk umum persamaan regresi spasial tanpa interaksi variabel eksogen dan endogen.

$$
\begin{gathered}
y=\rho W y+X \beta+u \\
u=\lambda W u+\varepsilon ; \varepsilon \sim N\left(0, \sigma^{2} I\right)
\end{gathered}
$$


Persamaan (1.6) dapat diubah menjadi:

$$
\begin{aligned}
y-\rho W y & =X \beta+u \\
(y-\rho W y) & =X \beta+u
\end{aligned}
$$

Persamaan (1.7) dapat diubah menjadi:

$$
\begin{gathered}
(I-\lambda W) u=\varepsilon \\
u=(I-\lambda W)^{-1} \varepsilon
\end{gathered}
$$

Jika persamaan (1.11) disubtitusikan ke persamaan(1.8) maka menjadi:

$$
\begin{aligned}
& (I-\rho W) y=X \beta+(I-\lambda W)^{-1} \varepsilon \\
& (I-\lambda W)^{-1} \varepsilon=(I-\rho W) y-X \beta \\
& \varepsilon=(I-\lambda W)(I-\rho W) y-X \beta
\end{aligned}
$$

Fungsi likelihood didefinisikan sebagai:

$$
L(X \mid \theta)=\Pi f(X ; \theta)
$$

Maka persamaan (1.12) dapat diubah menjadi:

$$
\begin{aligned}
\Pi f(\boldsymbol{y}) & =\quad \Pi f(\boldsymbol{\varepsilon})|J| \\
& =\left(\frac{1}{2 \pi \sigma^{2}}\right)^{\frac{n}{2}} \exp \left(-\frac{1}{2 \sigma^{2}}\left(\boldsymbol{\varepsilon}^{t} \varepsilon\right)|J|\right.
\end{aligned}
$$

Sebab terjadi transformasi fungsi $f(y)$ menjadi $f(\varepsilon)$ maka:

$$
\begin{aligned}
\Pi f(\boldsymbol{y}) & =\quad \Pi f(\boldsymbol{\varepsilon})|J| \\
& =\left(\frac{1}{2 \pi \sigma^{2}}\right)^{\frac{n}{2}} \exp \left(-\frac{1}{2 \sigma^{2}}\left(\boldsymbol{\varepsilon}^{t} \boldsymbol{\varepsilon}\right)|J|\right.
\end{aligned}
$$

Sehingga:

$$
\begin{aligned}
& L\left(\boldsymbol{y} \mid \rho, \lambda, \boldsymbol{\beta}, \sigma^{2}\right)=\left(\frac{1}{2 \sigma^{2}}\right)^{\frac{n}{2}}|J| \exp \left(-\frac{1}{2 \sigma^{2}}(((I-\right. \\
& \left.\lambda W)(I-\rho W) y-X \beta)^{t}((I-\lambda W)(I-\rho W) y-X \beta)\right)
\end{aligned}
$$

Nilai $|J|$ adalah:

$$
|J|=\left|\frac{\partial \varepsilon}{\partial y}\right|=|I-\lambda W||I-\rho W|
$$

Maka fungsi logaritma natural yang didapat sebagai langkah mendapatkan estimator adalah:

$$
\begin{aligned}
& \ln (L)=-\frac{n}{2} \ln (2 \pi)-\frac{n}{2} \ln \left(\sigma^{2}\right)+\ln |I-\rho W|-\frac{1}{2 \sigma^{2}}(((I- \\
& \left.\lambda W)(I-\rho W) y-X \beta)^{t}((I-\lambda W)(I-\rho W) y-X \beta)\right)
\end{aligned}
$$

Untuk mendapatkan nilai parameter dilakukan dengan memksimumkan fungsi logaritma natural likelihood. Estimasi parameter model spasial durbin dilakukan dengan membuat fungsi likelihood yang berasal dari persamaan

Berikut merupakan hasil estimasi parameter dengan metode MLE dari persamaan (1.16).

Tabel 1. Estimasi Parameter Model

\begin{tabular}{cc}
\hline Model & $\hat{\beta}$ \\
\hline Spatial Lag Model $(\lambda=0)$ & $\left(X^{t} X\right)^{-1} X^{t}(I-\rho W) Y$ \\
\hline Spatial Error Model $(\rho=0)$ & $\left((x-\hat{\lambda} W X)^{t}(x-\hat{\lambda} W X)\right)^{-1}\left((x-\hat{\lambda} W X)^{t}(x-\hat{\lambda} W X)\right)$ \\
\hline
\end{tabular}

\subsection{Penimbang Spasial}

Hubungan ketetanggaan antar lokasi dapat diekspresikan mejadi matriks $n \times n$ sesuai dengan jumlah wilayah amtan. Penimbang spasial diciptakan sebagai solusi atas ketidakadilan derajat wilayah yang berbeda-beda (Fischer, 2011). Matriksi penimbang spasial didefinisikan sebagai

$$
W=\left(\begin{array}{ccc}
w_{11} & \cdots & w_{n} \\
\vdots & \ddots & \vdots \\
w_{n 1} & \cdots & w_{n n}
\end{array}\right)
$$

Nilai dari $w_{i j}$ adalah 1 jika wilayah $i$ bertetagga dengan wilayah $j$ dan nilai nol jika tidak bertetangga. Jenis matriks penimbang disesuakan dengan keadaaan wilayahnya. Ada tiga jenis matriks pembobot spasial berdasarkan jenis ketetanggaan. (Lesage,1999)
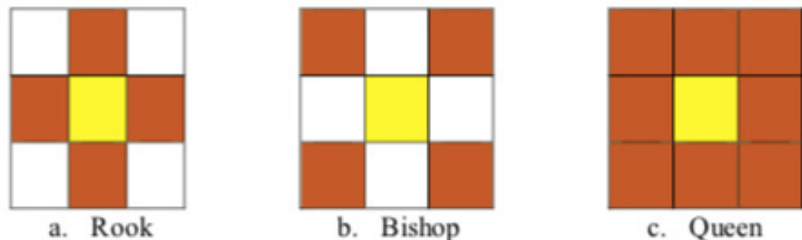

c. Queen

Gambar 1. Tipe Ketetanggaan

1. Rook contiguity, hubungan persentuhan sisi wilayah satu dengan sisi wilayah lain yang bertetangga. Jika wilayah bersentuhan sisi, $w_{i j}$ diberi nilai 1 dan 0 untuk sebaliknya.

2. Bishop contiguity, hubungan persentuhan titik sudut wilayah satu dengan sisi wilayah lain lain yang bertetangga. Jika wilayah bersentuhan titik sudut, $w_{i j}$ diberi nilai 1 dan 0 untuk sebaliknya.

3. Queen contiguity, hubungan persentuhan sisi maupun titik sudut suatu wilayah satu dengan wilayah yang lain. Jika wilayah bersentuhan sisi serta titik sudut, $w_{i j}$ diberi nilai 1 dan 0 untuk sebaliknya.

Nilai $w_{i j}$ tiap objek dalam penelitian ini telah distandarisasi menjadi nilai $w_{\mathrm{ij}}$ awal objek dibagi dengan jumlah baris dengan tujuan menstabilkan varians (Carl,2007)

\subsection{Tingkat Pengangguran Terbuka}

Yanuar (2009) mendefinisikan bahwa pengangguran adalah keadaan di mana angkatan kerja yang ingin memperoleh pekerjaan tapi belum mendapatkannya. Orang yang mencari pekerjaan, mempersiapkan usaha, orang yang tidak mencari pekerjaan sebab merasa tidak mungkin mendapat kerja, atau orang yang sudah punya pekerjaan namun belum mulai bekerja didefinisikan oleh Badan Pusat Statistik sebagai pengangguran terbuka/ penuh. Pengangguran terbuka juga dapat disebabkan karena kemajuan teknologi, serta kegiatan ekonomi yang menurun. Untuk mengetahui angka pengangguran tersebut yang diperhatikan bukanlah jumlah pengangguran, namun tingkat pengangguran terbuka yang dinyatakan sebagai persentase dari angkatan kerja (Sukirno, 2006). 


\subsection{Penduduk Miskin}

Penduduk miskin adalah penduduk yang memiliki pengeluaran perkapita perbulan lebih kecil dari garis kemiskinan. Garis kemiskinan adalah suatu garis yang mennjukkan nilai pengeluaran makanan per orang untuk memenuhi kebutuan dasar 2100 kkal perhari ditambah dengan pengeluaran non makanan selama satu bulan (BPS, 2010). Arsyad (2010) menjelaskan bahwa kemiskinan dapat terjadi karena anggota masyarakat tidak atau belum berpartisipasi dalam proses perubahan yang disebabkan ketidakmampuan dalam kepemilikian faktor produksi atau kualitas yang kurang memadai. Salah satu penyebab ketidakmampuan ini adalah karena tidak memiliki pekerjaan. Cutler (1991) menganalisis pengaruh variabel ekonomik makro seperti inflasi dan pengangguran terhadap kemiskinan, dan memberikan hasil bahwa pengangguran memberi pengaruh yang signifikan dan positif terhadap tingkat kemiskinan.

\subsection{Indeks Pembangunan Manuasia}

Indeks Pembangunan Manusia merupakan pengukuran dari harapan hidup, pendidikan dan standar hidup untuk semua negara. IPM dipakai untuk menilai aspek kualitas pembangunan suatu wilayah dan mengukur pengaruh kebijakan terhadap kualitas hidup (BPS,2015). Indeks Pembangunan Manusia merupakan nilai tunggal yang tersusun atas tiga dimensi pokok pembangunan yang dianggap merupakan kebutuhan dasar manusia. Ketiga dimensi tersebut adalah memiliki umur panjang dan sehat, berpengetahuan dan berketerampilan serta akses terhadap sumber daya yang digunakana untuk mencapai standar hidup layak. UNDP (1995), menyebutkan ada empat hal pokok yang perlu diperhatikan dalam pembangunan manusia yaitu produktivitas, pemerataan, kesinambungan dan peemberdayaan.

Badan Pusat Statistik (2014) menggunakan metode baru dalam perhitungan Indeks Pembangunan Manusia yaitu menggunakan komponen angka harapan hidup, angka harapan lama sekolah dan pengeluaran perkapita. Dapat disimpulkan bahwa Indeks Pembangunan Manusia merupakan aspek multidimensional. Indeks Pembangunan Manusia menilai kualitas ekonomi manusia yang ada di suatu wilayah dengan melihat besar pengeluaran perkapita. Jika suatu daerah memiliki pengeluaran perkapita rendah artinya penduduk tidak mengeluarkan banyak uang sebab tidak memiliki banyak pemasukan yang disebabkan oleh tidak bekerja.

\subsection{Produk Domestik Regional Bruto (PDRB)}

Untuk melihat pertumbuhan ekonomi suatu wilayah digunakan suatu indikator yang disebut Produk Domestik Bruto. Todaro (1997), menjelaskan PDRB per kapita di suatu daerah mencerminkan rata-rata kemampuan pendapatan masyarakat untuk memenuhi kebutuhannya terutama kebutuhan pokok. Secara umum, PDRB didefinisikan sebagai jumlah nilai tambah yang dihasilkan oleh seluruh lapangan usaha dalam suatu wilayah (BPS). Ketika nilai Produk Domestik Regional Bruto mengalami penurunan nilai maka akan berdampak pada konsumsi rumah tangga.

\section{METODOLOGI PENELITIAN}

\subsection{Variabel Penelitian}

Data yang digunakan merupakan data cross-section tahun 2018 yang diperoleh dari Badan Pusat Statistik mengenai data provinsi Bangka Belitung. Pengolahan data dilakukan dengan bantuan software R-Studio dan Q.GIS 3.8. Terdapat tujuh amatan yang merupakan seluruh kabupaten/ kota di provinsi tersebut. Berikut merupakan variabel yang digunakan dalam penelitian ini beserta skala pengukuran masing-masing variabel.

Tabel 2. Deskripsi Variabel

\begin{tabular}{cccc}
\hline No. & $\begin{array}{c}\text { Nama } \\
\text { Operasional }\end{array}$ & Variabel & $\begin{array}{c}\text { Skala } \\
\text { Pengukuran }\end{array}$ \\
\cline { 1 - 3 } 1 & $(\mathrm{Y})$ & $\begin{array}{c}\text { Tingkat Pengangguran } \\
\text { Terbuka }\end{array}$ & \\
\cline { 1 - 3 } & $(\mathrm{X} 1)$ & $\begin{array}{c}\text { Indeks Pembangunan } \\
\text { Manusia }\end{array}$ & \\
\cline { 1 - 2 } 2 & $(\mathrm{X} 2)$ & Jumlah Penduduk Miskin & \\
\cline { 1 - 2 } 4 & $(\mathrm{X} 3)$ & $\begin{array}{c}\text { Pendapatan Domestik } \\
\text { Regional Bruto }\end{array}$ & \\
\hline
\end{tabular}

\subsection{Analisis Data}

Tahapan analisis pada penelitian ini adalah

1. Pembentukan OLS dan uji asumsi

Regresi linear berganda dibentuk sebagai dasar pembentukan regresi spasial. Pemenuhan asumsi perlu dilakukan untuk menjamin parameter yang dihasilkan adalah BLUE.

- Uji Asumsi Normalitas

Pengujian ini membuktikan bahwa error yang dihasilkan oleh regresi memiliki distribusi normal.

Hipotesis

$$
\begin{aligned}
& \mathrm{H}_{0}: \varepsilon \sim N(0,1) \\
& \mathrm{H}_{1}: \varepsilon \neq N(0,1) \\
& \text { Statistik Uji } \\
& \mathrm{T}_{3}=\mathrm{T}_{3}=\frac{1}{D}\left[\sum_{i=1}^{k} a_{i}\left(X_{n-i+1}-X_{i}\right)\right]^{2} \\
& \mathrm{D}=\mathrm{D}=\sum_{i=1}^{n}\left(X_{i}-\bar{X}\right)^{2}
\end{aligned}
$$

dimana:

$$
\begin{aligned}
a_{\mathrm{i}} & =\text { Koefisien Shapiro Wilk } \\
X & =\text { Data ke }-i \\
\bar{X} & =\text { Rata-rata dari data }
\end{aligned}
$$

Keputusan : Tolak $\mathrm{H}_{0}$, jika $\mathrm{T}_{3}>\alpha$

- Uji Asumsi Heteroskedastisitas

Pengujian ini membuktikan bahwa adanya perbedaan karakteristik dari pengamatan yang satu dengan yang lain

Hipotesis

$$
\mathrm{H}_{0}: \sigma_{1}^{2}=\sigma_{2}^{2}=\ldots=\sigma_{n}{ }^{2}=\sigma^{2}
$$

(tidak terjadi heterogenitas)

$\mathrm{H}_{1}$ : minimal ada sepasang varians yang tidak sama (terjadi heterogenitas) 
Statistik Uji

$$
B P=\frac{1}{2} \boldsymbol{h}^{t} \boldsymbol{Z}\left(\boldsymbol{Z}^{t} \boldsymbol{Z}\right)^{-1} \boldsymbol{Z}^{t} \boldsymbol{h}
$$

dimana:

$$
\begin{aligned}
\boldsymbol{h}= & \left(h_{1}, h_{2}, \ldots, h_{n}\right)^{\mathrm{t}} \text { dengan } h_{i}=\frac{e_{i}^{2}}{\sigma^{2}}-1 \\
e_{i}= & y_{i}-\widehat{y}_{i}\left(\widehat{y}_{i} \text { dari hasil regresi }\right) \\
\boldsymbol{Z}= & \text { Matriks berukuran nilai setiap } n \times(k+l) \\
& \text { pengamatan yang telah di normalisasi }
\end{aligned}
$$

Keputusan : Tolak $\mathrm{H}_{0}$, jika $B P>\chi_{(k)}{ }^{2}$

- Uji Asumi Autokorelasi

Pengujian ini membuktikan bahwa error pengamatan tidak saling terkait baik waktu ataupun ruang.

$$
\begin{aligned}
& \text { Hipotesis } \\
& \mathrm{H}_{0}: \rho=0 \\
& \mathrm{H}_{1}: \rho>0
\end{aligned}
$$

Statistik Uji

$$
\mathrm{D}=\frac{\sum_{i=2}^{n}\left(e_{i}-e_{i-1}\right)^{2}}{\sum_{i=1}^{n} e_{i}^{2}}
$$

dimana:

$$
e_{i}=\text { error regresi amatan } \mathrm{ke}-i
$$
berikut

Keputusan : Tolak $\mathrm{H}_{0}$, jika nilai $d$ memenuhi kriteria

$$
\begin{array}{ll}
0<d<d \mathrm{~L} & : \text { autokorelasi positif } \\
4-d \mathrm{~L}<d<4 & \text { : autokorelasi negative }
\end{array}
$$

- Uji Asumsi Multikolinearitas

Pengujian ini menguji apakah model regresi ditemukan adanya korelasi antar variabel independent.

\section{- $\quad$ Statistik Uji}

Nilai variance inflation factor (VIF) yang menunjukkan setiap variabel independent manakah yang dijelaskan oleh variabel independent lainnya.

Keputusan:TerjadimultikolinearitasjikanilaiVIF $>10$.

\section{Pembentukan matriks penimbang spasial}

Matriks yang digunakan dalam penelitian ini adalah queen contiguity dengan alasan wilayah provinsi Bangka Belitung saling bersentuhan sudut dan sisi walaupun terdapat pulau yang terpisah tetapi tetap memiliki tetangga yang bersentuhan sudut dan sisi. Matriks penimbang lain yang digunakan sebagai perbandingan adalah matriks

3. Pengujian dependensi spasial

Pengujian ini bertujuan untuk mengetahui ketergantungan spasial dalam model dan variabel. Anselin (1988) menyebutkan bahwa ada dua metode yaitu Moran's I dan Lagrange Multiplier.

- Uji Moran's I.

Pengujian ini merupakan sebuah uji statistik yang bertujuan untuk menguji korelasi antar lokasi pada satu variabel atau dependensi spasial (Lesage, 1999).

\section{Hipotesis}

$\mathrm{H}_{0}: I=0$ (tidak ada dependensi antar lokasi)

$\mathrm{H}_{1}: I \neq 0$ (ada dependensi antar lokasi)
Statistik Uji

$$
Z=\frac{I-E(I)}{\sqrt{\operatorname{var}(I)}}
$$

dimana:

$$
I=\frac{n \sum_{i=1}^{n} \sum_{j=1}^{n} \boldsymbol{w}_{i j}\left(y_{i}-\bar{y}\right)\left(\boldsymbol{y}_{j}-\bar{y}\right)}{S_{0} \sum_{i=1}^{n}\left(y_{i}-\bar{y}\right)^{2}}
$$

$$
\begin{aligned}
& \operatorname{var}(I)=\frac{n\left[\left(n^{2}-3 n+3\right) S_{1}-n S_{2}+2 S_{0}^{2}\right]}{(n-1)(n-2)(n-3) S_{0}^{2}}-\frac{k\left[\left(n^{2}-n\right) S_{1}-n S_{2}+2 S_{0}^{2}\right.}{(n-1)(n-2)(n-3) S_{0}^{2}}-\left[-\frac{1}{n-1}\right]^{2} \\
& \mathrm{~S}_{1}=\frac{1}{2} \sum_{i \neq j}^{n}\left(\boldsymbol{w}_{i j}+\boldsymbol{w}_{j i}\right)^{2} ; \mathrm{S}_{2}=\sum_{i \neq j}^{n}\left(\boldsymbol{w}_{i}+\boldsymbol{w}_{. i}\right)^{2} ; \mathrm{S}_{0}= \\
& \sum_{i=1}^{n} \sum_{j=1}^{n} \boldsymbol{w}_{i j} ; \boldsymbol{w}_{i .}=\sum_{j=1}^{n} \boldsymbol{w}_{i j} ; \boldsymbol{w}_{. i}=\sum_{j=1}^{n} \boldsymbol{w}_{j i}
\end{aligned}
$$

Keputusan : Tolak $\mathrm{H}_{0}$, jika $\left|Z_{\text {hitung }}\right|>Z_{\frac{\alpha}{2}}$

Nilai dari indeks $I$ terletak diantara -1 hingga 1. Penggunaan dari nilai $I$, selain sebagai komponen statistik uji, adalah sebagai identifikasi pola penyebaran kewilayahan dari variabel yang ada. Jika nilai $I>I_{0}=-\frac{1}{n-1}$ maka memiliki pola mengelompok, jika $I<I_{0}$ maka memiliki pola menyebar dan jika $I=I_{0}$ maka tidak memiliki autokorelasi.

Indeks Moran tiap variabel dapat disajikan menjadi scatterplot yang memuat wilayah amatan di masing-masing kuadran. Zhukov (2010) menjelaskan bahwa ada empat kuadran pada Moran Scatterplot diantaranya adalah

\begin{tabular}{l|c} 
Kuadran I & Kuadran IV \\
\hline Kuadran II & Kuadran III
\end{tabular}

Gambar 1. Kuadran Moran Scatterplot

- $\quad$ Kuadran I, HH (High-High) menunjukkan daerah mempunyai nilai pengamatan tinggi dikelilingi oleh daerah yang mempunyai nilai pengamatan tinggi.

- $\quad$ Kuadran II, LH (Low-High) menunjukkan bahwa daerah yang mempunyai nilai pengamatan rendah dikelilingi oleh daerah yang mempunyai nilai pengamatan tinggi.

- Kuadran III, LL (Low-low) menunjukkan bahwa daerah yang mempunyai nilai pengamatan rendah dikelilingi oleh daerah yang mempunyai pengamatan rendah

- $\quad$ Kuadran IV, HL (High-low) menunjukkan bahwa daerah yang mempunyai nilai pengamatan tinggi dikelilingi oleh daerah yang mempunyai nilai pengamatan rendah.

Nilai pengamatan yang dimaksud adalah nilai yang akan diuji secara spasial. Pada penelitian ini adalah tingkat seluruh variabel penelitian.

- $\quad$ Uji Lagrange Multiplier

Pengujian ini untuk menentukan apakah model OLS yang akan dikembangkan memiliki efek spasial atau tidak. Terdapat dua jenis pengujian lagrange multiplier yaitu lagrange multipler biasa dan robust lagrange multiplier yang masing-masing mempunyai dua jenis pengujian yaitu lag dan error. Robust lagrange multiplier digunakan jika pada uji lagrange multiplier biasa terdapat ketidakpastian dalam mengetahui ketergantungan yang dimiliki oleh data. 
Tabel 3. Statistik Uji Lagrange Multiplier

\begin{tabular}{|c|c|c|}
\hline HIPOTESIS & Biasa & Robust \\
\hline $\begin{array}{l}\text { Lag } \\
\mathrm{H}_{0}:=0 \text { (tidak ada dependensi spasial) }\end{array}$ & $\left(\frac{e^{\prime} W y}{\sigma^{2}}\right)^{2}$ & {$\left[\left(\frac{e^{\prime} W y}{\sigma^{2}}\right)-\frac{e^{t} W e}{\sigma^{2}}\right]^{2}$} \\
\hline $\mathrm{H}_{1}: \neq 0$ (ada dependensi spasial) & $\frac{\overline{(W X \beta)^{t} M W X \beta+\operatorname{tr}\left[\left(W^{t}+W\right) W\right.}}{\sigma^{2}}$ & $\frac{\overline{(W X \beta)^{t} M W X \beta+\operatorname{tr}\left[\left(W^{t}+W\right) W\right.}}{\sigma^{2}}$ \\
\hline $\begin{array}{l}\text { Error } \\
\mathrm{H}_{0}:=0 \text { (tidak ada dependensi spasial) }\end{array}$ & $\left(\frac{e^{t} W e}{\sigma^{2}}\right)^{2}$ & {$\left[\left(\frac{e^{t} W e}{\sigma^{2}}\right)-\frac{\operatorname{tr}\left(W W+W^{\prime} W\right)}{\frac{e^{t} W Y}{\sigma^{2}}}\right]^{2}$} \\
\hline $\mathrm{H}_{1}: \neq 0$ (ada dependensi spasial) & $\frac{1}{\operatorname{tr}\left[\left(W^{t}+W\right) W\right]}$ & $\frac{\operatorname{tr}\left[\left(W^{t}+W\right) W\right]\left(1-\operatorname{tr}\left[\left(W^{t}+W\right) W\right]\right)}{\frac{(W X \beta)^{t} M W X \beta+\operatorname{tr}\left[\left(W^{t}+W\right) W\right.}{\sigma^{2}}}$ \\
\hline
\end{tabular}

$$
\begin{aligned}
& \text { dimana: } \quad e=\text { Residual OLS } \quad n=\text { Banyak observasi } \\
& W=\text { Matriks Pembobot Spasial } \quad \beta=\text { estimasi parameter OLS } \\
& M=I-X\left(X^{\imath} X\right)^{-1} X^{\imath} \quad \sigma^{2}=\frac{e^{t} e}{n}
\end{aligned}
$$

Keputusan : Tolak $\mathrm{H}_{0}$, jika $p$-value $<\alpha$. Lagrange multiplier robust lebih sensitif untuk pengujian dependensi spasial dibandingkan pengujian lagrange multiplier biasa (Grekousis, 2020).

4. Pembentukan model spasial dan pengujian asumsi

Model dbentuk berdasarkan kriteria signifikansi lagrange multiplier. Anselin (2014) memberikan aturan dalam pemilihan model spasial yang akan dibentuk dari regresi OLS. Pertama melihat nilai signifikansi dari lagrange multiplier biasa, jika salah satu diantaranya, lag atau error, signifikan maka jenis model yang dibentuk berdasarkan nilai LM yang signifikan. Namun, jika keduanya signifikan maka melihat nilai robust lagrange multiplier dan melakukan pemilihan yang sama dengan sebelumnya. Jika kedua nilai LM biasa tidak signifikan, namun salah satu/kedua nilai robust lagrange multiplier signifikan dan uji asumsi non-autokorelasi OLS terlanggar,. Jika seluruh nilai lagrange multiplier, baik biasa atau robust, tidak signifikan maka tidak perlu menggunakan OLS. Setelah model terbentuk, maka perlu dilakukan kembali uji asumsi OLS yang ada untuk menjamin bahwa penggunaan model spasial memiliki estimator yang unbiased.

\section{Pemilihan Model}

Setelah model telah terbentuk, dilakukan pemilihan model berdasarkan nilai Akaike's Information Criterion (AIC). Konsep dari nilai ini adalah menggunakan informasi dari likelihood ratio yang merupakan nilai maksimum dari perbandingan model bebas dengan model yang ingin dipilih. AIC dapat dihitung melalui rumus

$$
A I C=-2 \log (L)+2 k
$$

dimana:

$$
\begin{aligned}
& L=\text { likelihood ratio } \\
& k=\text { jumlah parameter dalam model. }
\end{aligned}
$$

Kritreia pemilihan model yang terbaik adalah jika suatu model memiliki angka $A I C$ yang lebih kecil daripada model lain (tidak terpengaruh tanda).

\section{HASIL DAN PEMBAHASAN}

\subsection{Analisis Deskriptif}
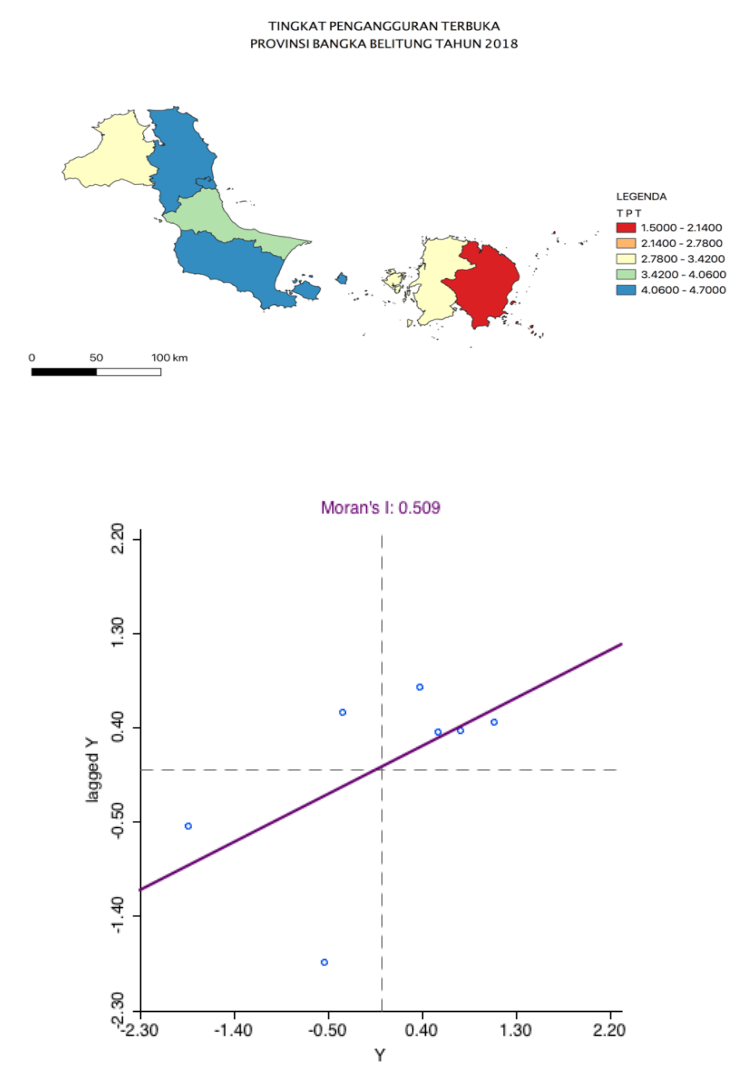

Gambar 2. Peta Tematik dan Moran's I Tingkat Pengangguran Terbuka

Tingkat pengangguran terbuka, berdasarkan hasil pengolahan, provinsi Bangka Belitung memiliki nilai minimum yang dimiliki kabupaten Belitung Timur sebesar 1.50 dan nilai maksimum sebesar 4.70 yang dimiliki oleh kota Pangkalpinang. Selanjutnya, jika dilihat dari nilai 
indeks moran didapatkan nilai sebesar 0.509. Nilai ini lebih besar daripada nilai $I_{0}$ yaitu -0.1667 dan terletak diantara $0<I$. Maka, pola penyebaran tingkat pengangguran terbuka adalah mengelompok serta menunjukkan gejala autokorelasi spasial positif. Hal ini menunjukkan bahwa tingkat penganggurn terbuka provinsi Bangka Belitung menunjukkan adanya kemiripan tiap wilayah. Jika diamati lebih lanjut, dari gambar 2, empat dari tujuh kabupaten/kota provinsi Bangka Belitung terletak pada kuadran empat. Kabupaten/kota tersebut adalah kabupaten Bangka, kota Pangkalpinang, kabupaten Bangka Tengah, kabupaten Bangka Selatan. Keempat kabupaten/kota tersebut memiliki nilai yang tinggi namun dikelilingi nilai yang rendah. Kemudian, baik kabupaten Belitung dan Belitung Timur memiliki kemiripan sebab terletak pada satu pulau yang terpisah dari kabupaten lain dan terletak pada kuadran dua yang artinya memiliki nilai pengamatan yang rendah namun dikelilingi pengamatan yang tinggi. Kabupaten Bangka Barat cenderung dikelilingi oleh nilai amatan yang tinggi dan juga kabupaten ini memiliki nilai yang tinggi juga untuk variabel tingkat pengangguran terbuka.
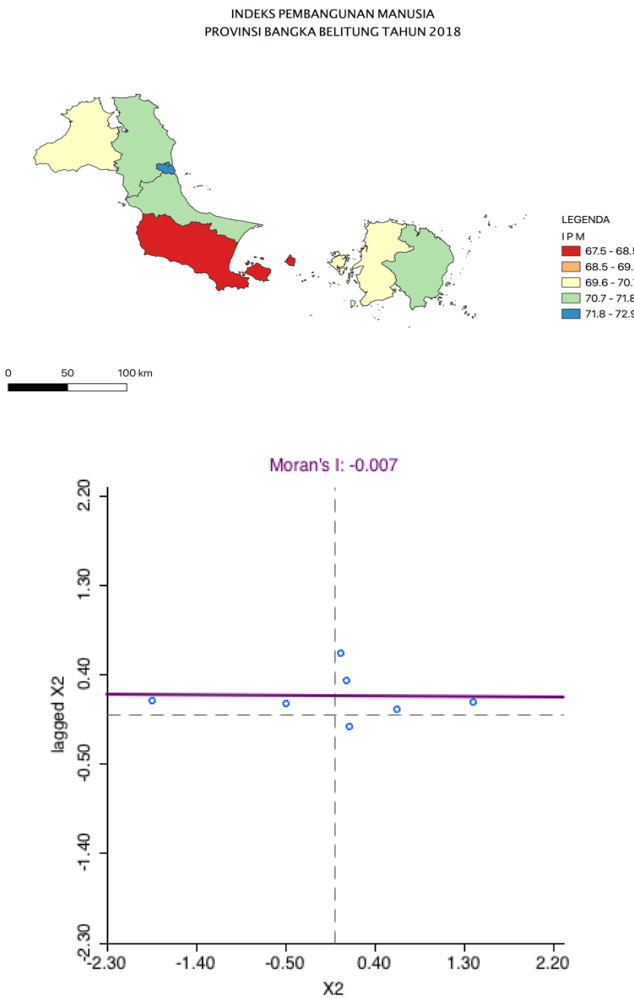

Gambar 3. Peta Tematik dan Moran's I Indeks Pembangunan Manusia

Melalui peta tematik yang ada dapat diketahui bahwa kabupaten Bangka dan Bangka Tengah memiliki kemiripan nilai amatan. Nilai Indeks Pembangunan Manusia tertinggi diperoleh kota Pangkalpinang sebesar 67.47 sedangkan nilai terendah diperoleh kabupaten Bangka Selatan sebesar 72.86. Hal ini menunjukkan bahwa kualitas sumber daya manusia di kota lebih maju daripada di kabupaten sebab telah tersedianya berbagai macam penunjang seperti fasilitas sekolah yang memadai, fasilitas kesehatan yang mudah terjangkau, dan rata-rata nilai pengeluaran perkapita yang telah diatas garis kemiskinan. Aspek kewilayahan variabel ini, jika melihat nilai Moran's I, adalah cenderung menyebar. Keragaman nilai pengamatan pada variabel ini cenderung tidak ada perbedaan namun tersebar diseluruh bagian pulau sehingga jika dilihat,pada gambar 3, hampir seluruh kabupaten/kota berada pada kuadran empat dimana daerah mempunyai nilai pengamatan yang tinggi namun dikelilingi oleh pengamatan rendah. Jika merujuk nilai batasan penentuan status autokorelasi spasial, variabel ini cenderung tidak memiliki autokorelasi spasial sebab memiliki nilai hampir sama dengan nol.

PROVINSI BANGKA BELITUNG TAHUN 2018

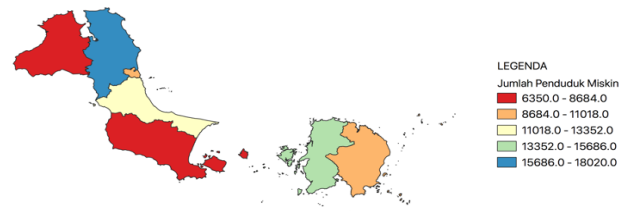

${ }^{0} \quad \operatorname{SO}^{100 \mathrm{~km}}$

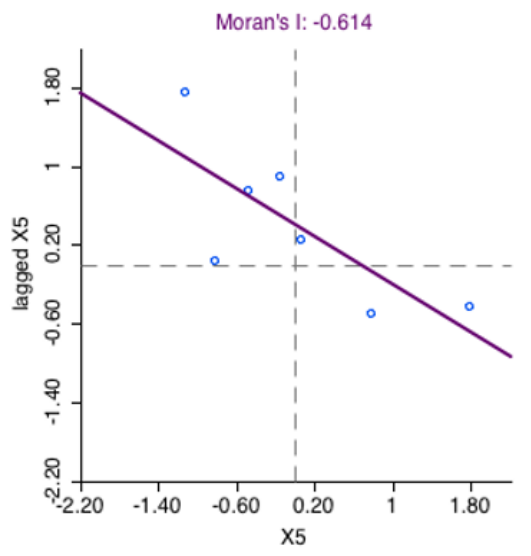

Gambar 4. Peta Tematik Jumlah Penduduk Miskin dan Moran's I Jumlah Penduduk Miskin

Jumlah penduduk miskin provinsi Bangka Belitung memiliki nilai minimum yaitu kabupaten Bangka Barat sebesar 6350 penduduk serta memiliki nilai maksimum yaitu kabupaten Bangka sebesar 18020 penduduk. Semakin tinggi nilai jumlah penduduk miskin suatu daerah maka semakin layak daerah tersebut dikatakan sebagai kantong kemiskinan suatu provinsi. Selanjutnya, jika melihat nilai moran didapatkan nilai sebesar -0.614. Nilai ini terletak pada $-1 \quad I<0$ serta lebih kecil daripada -0.1667 yang artinya memiliki autokorelasi negatif dan nilai amatan tersebar secara berkelompok. Nilai negatif menunjukkan pola ketetanggan yang tidak sistematis atau terstruktur. Jika diamati lebih lanjut,pada gambar 4, kuadran dominan yang ditempati oleh kabupaten/kota provinsi Bangka Belitung adalah kuadran satu yang mengindikasikan bahwa kabupaten/kota tersebut memiliki nilai pengamatan yang tinggi dan juga dikelilingi oleh daerah yang memiliki nilai pengamatan yang tinggi. Kabupaten/kota tersebut adalah kabupaten Bangka Barat, kota Pangkalpinang, kabupaten Bangka Selatan, dan kabupaten Belitung Timur. 
PRODUK DOMESTIK REGIONAL BRUTO PROVINSI BANGKA BELITUNG TAHUN 2018

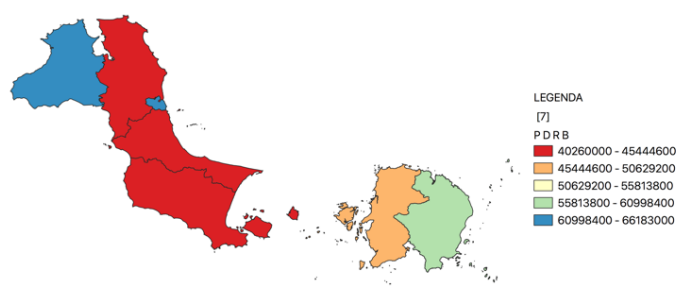

$\stackrel{\circ}{25} \quad 50 \mathrm{~km}^{2}$

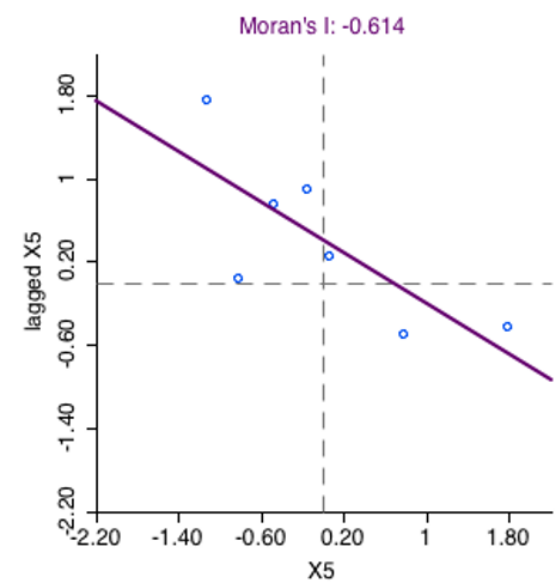

Gambar 5 Peta Tematik dan Moran's I Produk Domestik Regional Bruto

Produk Domestik Regional Bruto provinsi Bangka Belitung memiliki nilai minimum sebesar Rp 40,260,000 yang diperoleh kabupaten Bangka dan nilai maksimum sebesar Rp 66,183,000 yang diperoleh kabupaten Bangka Barat. Semakin besar nilai Pendapatan Domestik Regional Bruto (PDRB) semakin mengindikasikan bahwa kabupaten/ kota tersebut merupakan sentral industri atau dapat dikatakan produksi yang dihasilkan di kabupaten/kota tersebut lebih besar daripada kabupaten/kota yang lain. Selanjutnya, jika melihat nilai moran didapatkan nilai sebesar -0.332 . Nilai ini terletak pada $1 \quad I<0$ serta lebih kecil daripada -0.1667 yang artinya memiliki autokorelasi negatif dan nilai amatan tersebar secara berkelompok. Pada diagram kuadran moran's didapatkan bahwa hampir setiap kabupaten/kota terdapat di setiap kuadran. Ini mengindikasikan bahwa aspek kewilayahan yang lemah dan tidak terstruktur.

\subsection{Analisis Inferensia}

\subsubsection{Pembentukan Model OLS}

Model OLS digunakan sebagai dasar pembentukan model spasial. Variabel yang digunakan dalam model telah distandarisasi satuan menggunakan proses akar kuadrat. Berikut adalah nilai estimasi parameter yang terbentuk pada model OLS.

Tabel 4. Estimasi Parameter Model OLS

\begin{tabular}{ccc}
\hline Parameter & Estimasi & p-value \\
\hline$\beta_{0}$ & 1.9618435 & 0.934 \\
\hline Sqrt $(\mathrm{X} 1)$ & 0.1548609 & 0.963 \\
\hline Sqrt $(\mathrm{X} 2)$ & -0.0008977 & 0.961 \\
\hline Sqrt $(\mathrm{X} 3)$ & -0.0001844 & 0.711 \\
\hline
\end{tabular}

Jika melihat dari kolom $p$-value diketahui seluruh variabel memiliki nilai $>\alpha(0.1)$. Maka, tidak ada satu variabel yang signifikan didalam model. Selanjutnya, hasil tersebut dijadikan dasar pembentukan regresi spasial dengan menguji terlebih dahulu ada/tidaknya pelanggaran asumsi yang ada.

\subsubsection{Pengujian Asumsi OLS \\ - Asumsi Normalitas}

Pengujian menggunakan statistik uji Shapiro-Wilks yang memberikan hasil sebagai berikut

Tabel 5. Hasil Pengujian Asumsi Normalitas

\begin{tabular}{ccc}
\hline Statistik Uji & p-value & Keputusan \\
\hline Shapiro-Wilks & 0.4187 & Gagal tolak $\mathrm{H}_{0}$ \\
\hline
\end{tabular}

Karena hasil $p$-value menunjukkan nilai $>\alpha(0.1)$, maka dapat disimpulkan bahwa error yang dihasilkan berdistribusi normal. Dengan kata lain, asumsi normalitas telah terpenuhi.

\section{- Asumsi Homoskedastisitas}

Pengujian menggunakan statistik uji BreuschPagan yang memberikan hasil sebagai berikut

Tabel 6. Hasil Pengujian Asumsi Homoskedastisitas

\begin{tabular}{ccc}
\hline Statistik Uji & p-value & Keputusan \\
\hline Breusch-Pagan & 0.2857 & Gagal tolak $\mathrm{H}_{0}$ \\
\hline
\end{tabular}

Karena hasil $p$-value menunjukkan nilai $>\alpha(0.1)$, maka dapat disimpulkan bahwa error yang dihasilkan memiliki varians konstan. Dengan kata lain, asumsi homoskedastisitas telah terpenuhi.

\section{- Asumsi Multikolinearitas}

Pengujian menggunakan statistik uji Variance Inflation Factor (VIF) yang memberikan hasil sebagai berikut

Tabel 7. Hasil Pengujian Asumsi Non-Multikolinearitas

\begin{tabular}{ccc}
\hline Statistik Uji & Nilai & Keputusan \\
\hline \multirow{4}{*}{ VIF } & SQRT(X1) $=3.114404$ & \\
& SQRT(X2) $=3.431010$ & Tidak terjadi \\
& SQRT $(X 3)=3.829378$ & multikolinearitas
\end{tabular}

Karena nilai VIF seluruh variabel kurang dari sepuluh maka dapat dikatakan asumsi non-multikolinearitas telah terpenuhi.

\section{- Asumsi AutoKorelasi}

Pengujian menggunakan statistik uji DurbinWatson yang memberikan hasil sebagai berikut

Tabel 8. Hasil Pengujian Asumsi Non-Autokorelasi

\begin{tabular}{ccc}
\hline Statistik Uji & p-value & Keputusan \\
\hline Durbin-Watson & 0.564 & Gagal tolak $\mathrm{H}_{0}$ \\
\hline
\end{tabular}

Karena hasil $p$-value menunjukkan nilai $>\alpha(0.1)$, maka dapat disimpulkan bahwa error yang dihasilkan tidak terkait satu dengan yang lain. Dengan kata lain, asumsi nonautokorelasi telah terpenuhi. 
Secara umum, model OLS yang dihasilkan telah memenuhi asumsi dan dapat dikatakan layak untuk digunakan sebagai dasar pembentukan permodelan spasial.

\subsubsection{Pengujian Efek Spasial}

\section{- Uji AutoKorelasi Spasial}

Pengujian menggunakan statistik uji Moran's I dengan menggunakan matriks penimbang kewilayahan queen. Pengujian memberikan hasil sebagai berikut.

Tabel 9. Hasil Pengujian Autokorelasi Spasial

\begin{tabular}{lcl}
\hline Statistik Uji & p-value & Keputusan \\
\hline $\begin{array}{l}\text { Moran's I dengan Queen } \\
\text { Contiguity }\end{array}$ & 0.0465 & Tolak $\mathrm{H}_{0}$ \\
\hline
\end{tabular}

Karena hasil $p$-value menunjukkan nilai $<\alpha(0.1)$, maka dapat disimpulkan bahwa error yang dihasilkan terkait kewilayahan satu dengan yang lain. Dengan kata lain, asumsi autokorelasi spasial telah terpenuhi.

\section{- Uji Dependensi Spasial}

Pengujian menggunakan empat tipe statistik uji lagrange multiplier yang seluruhnya menggunakan matriks penimbang kewilayahan queen. Pengujian memberikan hasil sebagai berikut

Tabel 10. Hasil Pengujian Dependensi Spasial

\begin{tabular}{|c|c|c|}
\hline Statistik Uji & p-value & Keputusan \\
\hline Lagrange Multiplier (error) & 0.4136 & Gagal Tolak $\mathrm{H}_{\mathrm{c}}$ \\
\hline Lagrange Multiplier (lag) & 0.2497 & Gagal Tolak $\mathrm{H}_{\mathrm{c}}$ \\
\hline $\begin{array}{c}\text { Robust- Lagrange Multiplier } \\
\text { (error) }\end{array}$ & 0.01519 & Tolak $\mathrm{H}_{0}$ \\
\hline $\begin{array}{c}\text { Robust-Lagrange Multiplier } \\
\text { (lag) }\end{array}$ & 0.010408 & Tolak $\mathrm{H}_{0}$ \\
\hline
\end{tabular}

Terlihat bahwa hasil $p$-value untuk lagrange multipler menunjukkan nilai $>\alpha(0.1)$, sedangkan hasil $p$-value untuk robust lagrange multiplier keduanya signifikan $(<\alpha(0.1))$. Grekousis (2020) menyebutkan bahwa pengujian robust lagrange multiplier lebih sensitif terhadap kehadiran autokorelasi error spasial. Maka, melihat hasil uji lagrange multiplier tidaklah cukup ketika didalam model terdapat gejala autokorelasi spasial. Selanjutnya, karena kedua nilai robust lagrange multiplier signifikan maka model yang akan dibentuk adalah model spasial lag dan spasial error yang nantinya akan dipilih salah satu yang memenuhi kriteria pemilihan model.

\subsubsection{Model Spasial Lag}

Model spasial lag yang terbentuk menggunakan matriks penimbang kewilayahan spasial queen adalah sebagai berikut

\begin{tabular}{ccc}
\multicolumn{3}{c}{ Tabel 11. Hasil Estimasi Parameter Model Spasial Lag } \\
\hline Parameter & Estimasi & p-value \\
\hline$\beta_{0}$ & 1.9618435 & 0.6314 \\
\hline Sqrt(X1) & 0.1548609 & 0.7292 \\
\hline Sqrt(X2) & -0.0008977 & 0.5721 \\
\hline Sqrt(X3) & -0.0001844 & 0.8509 \\
\hline$\rho$ & 0.40049 & 0.20326 \\
\hline
\end{tabular}

Jika melihat dari kolom $p$-value diketahui estimasi seluruh variabel termasuk $\rho$ memiliki nilai $>\alpha(0.1)$. Maka, tidak ada satu variabel yang signifikan didalam model dan tidak terdapat ketergantungan spasial pada model. Selanjutnya, model tersebut dilakukan pengecekan asumsi OLS.

Tabel. 12. Hasil Pengujian Asumsi OLS Model Spasial Lag

\begin{tabular}{ccc}
\hline Pengujian & p-value & Keputusan \\
\hline Normalitas & 0.4366 & Gagal tolak $\mathrm{H}_{0}$ \\
Homoskedastisitas & 0.27232 & \\
\hline
\end{tabular}

Dari hasil pengujian terlihat bahwa model spasial lag telah memenuhi asumsi OLS.

\subsubsection{Model Spatial Error}

Model spasial error yang terbentuk menggunakan matriks penimbang kewilayahan spasial queen adalah sebagai berikut.

Tabel 13. Hasil Estimasi Parameter Model Spasial Error

\begin{tabular}{ccc}
\hline Parameter & Estimasi & p-value \\
\hline$\beta_{0}$ & 14.64706991 & 0.05781 \\
\hline $\operatorname{Sqrt}(\mathrm{X} 1)$ & -2.01974650 & 0.06581 \\
\hline $\mathrm{Sqrt}(\mathrm{X} 2)$ & 0.01632838 & 0.01957 \\
\hline $\operatorname{Sqrt}(\mathrm{X} 3)$ & 0.00034890 & 0.09455 \\
\hline$\lambda$ & 0.69902 & 0.090715 \\
\hline
\end{tabular}

Jika melihat dari kolom $p$-value diketahui estimasi seluruh variabel termasuk $\rho$ memiliki nilai $<\alpha(0.1)$. Maka, seluruh variabel signifikan didalam model dan terdapat ketergantungan spasial pada model. Selanjutnya, model tersebut dilakukan pengecekan asumsi OLS.

Tabel 14. Hasil Pengujian Asumsi OLS Model Spasial Lag

\begin{tabular}{ccc}
\hline Pengujian & p-value & Keputusan \\
\hline Normalitas & 0.2154 & Gagal tolak $\mathrm{H}_{0}$ \\
Homoskedastisitas & 0.6834 & \\
\hline
\end{tabular}

Dari hasil pengujian terlihat bahwa model spasial error telah memenuhi asumsi OLS.

\subsubsection{Pemilihan Model}

Setelah mendapatkan hasil estimasi parameter dan melakukan pengujian baik signifikansi variabel dan asumsi OLS, langkah selanjutnya adalah melakukan pemilihan model dengan dasar pemilihan menggunakan nilai Akaike Information Criterion (AIC). Berikut adalah nilai AIC dari kedua model.

Tabel 15. Nilai AIC Model

\begin{tabular}{ccc}
\hline Model & Likelihood Ratio & AIC \\
\hline Spatial Lag Model & 0.88541 & 12.243 \\
\hline Spatial Error Model & 1.64826 & 11.001 \\
\hline
\end{tabular}

Terlihat dari hasil AIC diatas bahwa model spasial error memiliki $A I C$ yang paling kecil. Lebih lanjut, jika melihat nilai signifikansi koefisien dependensi spasial pada model spasial error $(\lambda)$ signifikan daripada nilai koefisien dependensi spasial pada model lag $(\rho)$. Maka dapat disimpulkan bahwa model yang terpilih adala model spasial error dengan persamaan sebagai berikut 


$$
\begin{gathered}
\widehat{\operatorname{sqrt}(y})_{i}=14.64706991-2.0197465 \operatorname{sqrt}\left(X_{1 i}\right)+ \\
0.01632838 \operatorname{sqrt}\left(X_{2 i}\right)+0.00034890 \operatorname{sqrt}\left(X_{3 i}\right)+\hat{u} \\
\hat{u}=0.69902 \sum_{j=1 ; i \neq j}^{n} W_{i j} \hat{u}
\end{gathered}
$$

Dimana, $i, j$ merupakan nama tiap-tiap kabipaten. Seluruh variabel signifikan didalam model yang artinya variabel indeks pembangunan manusia, jumlah penduduk miskin, serta pendapatan domestic regional bruto mempengaruhi tingkat pengangguran terbuka di provinsi Bangka Belitung. Interpretasi dari nilai estimator tersebut adalah sama dengan interpretasi yang ada pada regresi OLS yaitu setiap kenaikan satu satuan varaibel $\mathrm{X}$ akan meningkatkan/menurunkan nilai variabel $\mathrm{Y}$ sebesar $\widehat{\beta}_{\imath}$ satuan.

\section{KESIMPULAN}

Dari serangkaian analisis yang dilakukan, maka dapat disimpulkan bahwa model yang terbentuk adalah model spasial error dengan seluruh variabel signifikan didalam model. Variabel yang terindikasi mengalami keterkatian kewilayahan, pada pengamatan ini, adalah variabel tingkat pengangguran terbuka, jumlah penduduk miskin serta pendapatan daerah regional bruto. Penelitian ini jauh akan lebih baik jika tersedia amatan waktu dari variabel lebih panjang (time series) sehingga dapat dilihat perbendaan dari setiap amatan waktu dan pengaruh masa lampau dapat dimasukkan ke dalam model. Selain itu, menambahkan variabel seperti jumlah penduduk muda, tingkat partisipasi kerja, pertumbuhan ekonomi serta inflasi juga direkomendasikan sebagai penyempurnaan model.

\section{DAFTAR PUSTAKA}

Anselin, L. (2003). An introduction to spatial regression analysis in R. University of Illinois, Urbana-Champaign.

Anselin, L., \& Bera, A. K. (1998). Introduction to spatial econometrics. Handbook of applied economic statistics, 237.

Chen, D., Moulin, B., \& Wu, J. (Eds.). (2015). Analyzing and modeling spatial and temporal dynamics of infectious diseases. John Wiley \& Sons, Incorporated.

Fischer, M. M., \& Wang, J. (2011). Spatial data analysis: models, methods and techniques. Springer Science \& Business Media.

Grekousis, G. (2020). Spatial Analysis Theory and Practice: Describe-Explore-Explain through GIS. Cambridge University Press.

Herdiani, E. T. (2018). Seleksi Model Multinomial Logit Melalui Akaike's Information Criterion (AIC). Jurnal Matematika, Statistika dan Komputasi, 4(1), 43-53.
Ilahi, R., Syamsuddin, M., \& Suparman, Y. (2014, November). MODEL SPASIAL DURBIN DENGAN EFEK TETAP UNTUK TINGKAT PENGANGGURAN TERBUKA DI PROVINSI KEPULAUA BANGKA BELITUNG. In Prosiding Seminar Nasional Statistika| Departemen Statistika FMIPA Universitas Padjadjaran (Vol. 4, No. 1, pp. 424-436).

Kutner, M. H., Nachtsheim, C. J., Neter, J., \& Li, W. (2005). Applied linear statistical models (Vol. 5). New York: McGraw-Hill Irwin.

Laswinia, Vonesa Devi (2016) Analisis Pola Hubungan Persentase Penduduk Miskin dengan Faktor Lingkungan, Ekonomi, dan Sosial Di Indonesia Menggunakan Regresi Spasial. Institut Teknologi Sepuluh Nopember

LeSage, J. P. (1999). The theory and practice of spatial econometrics. University of Toledo. Toledo, Ohio, 28(11).

Lozano-Gracia, N. (2010). Introduction to Spatial Econometrics.

Mahihody, A. Y., Engka, D. S., \& Luntungan, A. Y. (2018). PENGARUH UPAH DAN INDEKS PEMBANGUNAN MANUSIA (IPM) TERHADAP PENGANGGURAN DI KOTA MANADO. JURNAL BERKALA ILMIAH EFISIENSI, 18(3).

Mahroji, D., \& Nurkhasanah, I. (2019). Pengaruh Indeks Pembangunan Manusia Terhadap Tingkat Pengangguran di Provinsi Banten. Jurnal EkonomiQu, 9(1).

Mendez C. (2020). Spatial regression analysis in R. R Studio/RPubs. Available at https://rpubs.com/ quarcs-lab/tutorial-spatial-regression

Ningrum, S. S. (2017). Analisis Pengaruh Tingkat Pengangguran Terbuka, Indeks Pembangunan Manusia, Dan Upah Minimum Terhadap Jumlah Penduduk Miskin Di Indonesia Tahun 2011-2015. Jurnal Ekonomi Pembangunan, 15(2), 184-192.

Novianti, E. (2019). KESENJANGAN GENDER TINGKAT PENGANGGURAN TERBUKA DI INDONESIA. Jurnal Pendidikan dan Ekonomi, 8(2), 166-174.

Oktafianto, E. K., Achsani, N. A., \& Irawan, T. (2019). The Determinant of Regional Unemployment in Indonesia: The Spatial Durbin Models. Signifikan: Jurnal Ilmu Ekonomi, 8(2), 179-194.

Prasetya, K. A., \& Pasaribu, E. (2019). Analisis Spasial Produktivitas Setengah Penganggur di Indonesia Tahun 2017: Perbandingan dengan Sektor Primer. Jurnal Ekonomi dan Kebijakan Publik, 10(2), 125-139.

Priastiwi, D., \& Handayani, H. (2019). ANALISIS PENGARUH JUMLAH PENDUDUK, PENDIDIKAN, UPAH MINIMUM, DAN PDRB TERHADAP TINGKAT PENGANGGURAN 
TERBUKA DI PROVINSI JAWA TENGAH.

Diponegoro Journal of Economics, 1(1).

Probosiwi, R. (2016). Pengangguran dan Pengaruhnya terhadap Tingkat Kemiskinan. Jurnal Penelitian Kesejahteraan Sosial, 15(2), 89-100.

Rahmawati, R., Safitri, D., \& Fairuzdhiya, O. U. (2015). Analisis spasial pengaruh tingkat pengangguran terhadap kemiskinan di Indonesia (Studi kasus Provinsi Jawa Tengah). Media Statistika, 8(1), 23-30.

Rawlings, J. O., Pantula, S. G., \& Dickey, D. A. (2001). Applied regression analysis: a research tool. Springer Science \& Business Media.

Romhadhoni, P., Faizah, D. Z., \& Afifah, N. (2018). Pengaruh Produk Domestik Regional Bruto (PDRB) Daerah terhadap Pertumbuhan Ekonomi dan Tingkat Pengangguran Terbuka di Provinsi DKI Jakarta. Jurnal Matematika Integratif, 14(2), 113120.

Safitri, D. W., Darsyah, M. Y., \& Utami, T. W. (2014). Pemodelan Spatial Error Model (SEM) untuk Indeks Pembangunan Manusia (IPM) di Provinsi Jawa Tengah. Jurnal Statistika Universitas Muhammadiyah Semarang, 2(2).

Samadi, H., \& Asdi, Y. (2017). PENERAPAN MODEL REGRESI SPASIAL DALAM MENENTUKAN FAKTOR-FAKTOR YANG MEMPENGARUHI INDEKS PEMBANGUNAN MANUSIA DI KABUPATEN/KOTA PROVINSI SUMATERA BARAT. Jurnal Matematika UNAND, 6(4).

Sirait, A. F., Yulmardi, Y., \& Bhakti, A. (2018). Faktor-faktor yang mempengaruhi pengangguran terbuka di Provinsi Jambi. E-Jurnal Perspektif Ekonomi Dan Pembangunan Daerah, 7(3), 137-146.

Syaadah, L., \& Listyani, E. (2016). Spatial Autoregressive Model dan Matriks Pembobot Spasial Rook Contiguity untuk Pemodelan Gini Ratio di Indonesia Tahun 2014. Jurnal Matematika-S1, 5(4).

Vega, S. H., \& Elhorst, J. P. (2013, August). On spatial econometric models, spillover effects, and W. In 53rd ERSA Congress, Palermo, Italy.

Wuryandari, T., Hoyyi, A., Kusumawardani, D. S., \& Rahmawati, D. (2014). Identifikasi Autokorelasi Spasial Pada Jumlahpengangguran Di Jawa Tengah Menggunakan Indeks Moran. Media Statistika, 7(1), 1-10. 